Espai obert
Open space 
Nloma 2016, 34(1), 65-70

Revista de Psicologia, Ciències de l’Educació i de l'Esport

ISSN: $1138-3194$

Copyright $\odot 2016$

www.revistaaloma.net

\title{
Can Psychomotricity improve cognitive abilities in infants?
}

\author{
Maria Teresa Mas \& Judit Castellà \\ Universitat Autònoma de Barcelona
}

Received: 30-10-2015

Accepted: 17-2-2016

\section{Can Psychomotricity improve cognitive abilities in infants?}

Summary. The aim of this study was to determine whether participating in a psychomotricity programme at an early age improves cognition. Thirty infants (11 to 22 months of age) participated in the study. The MerrillPalmer-R test was administered before the intervention in order to measure the General Index of Development, Cognition and Motor Abilities. One group performed one session of psychomotricity per week, another group received two sessions per week, and a third (control) group did not perform any sessions. After intervention, the test scales were administered again. The group who received two weekly sessions obtained higher scores in all measures after intervention compared to baseline. The results suggest that systematic practice of psychomotricity can improve general development and cognition in infants, and that implementing this methodology could thus be useful in educative intervention.

Keywords: psychomotricity; cognition; development; toddlers

Pot la psicomotricitat millorar les habilitats cognitives en els nadons?

Resum. L'objectiu del present estudi és determinar si la participació en un programa de psicomotricitat a una edat primerenca millora la cognició. Trenta nadons (de 11 a 22 mesos d'edat) van participar en l'estudi. El test MerrillPalmer-R es va administrar abans de la intervenció per tal de mesurar l'índex general de Desenvolupament, Cognició i habilitats motores. Un grup de nens va realitzar una sessió de psicomotricitat per setmana, un altre grup va rebre dues sessions per setmana, i un tercer grup -control- no realitzar cap sessió. Després de la intervenció, les escales del test es van administrar de nou. El grup que va rebre dues sessions setmanals va obtenir les puntuacions més altes en totes les mesures després de la intervenció en comparació amb el nivell basal. Els resultats suggereixen que la pràctica sistemàtica de la psicomotricitat pot millorar el desenvolupament general i la cognició en els nadons, per la qual cosa podria ser útil per implementar aquesta metodologia en la intervenció educativa.

Paraules clau: Psicomotricitat; cognició; desenvolupament; nadons 


\section{Introduction}

The present study focuses on psychomotor training and its effects on cognition at an early age (11-22 months), a period that is characterized by a process of integration of children's bodies, emotions and cognition thanks to the joint development of sensory, perceptual, motor, and cognitive abilities. According to Herrero (2000), psychomotor intervention is an activity that is performed in order to enhance an individual's potential development through the use of the body, action and motion. These activities can be seen as tools that toddlers use to relate to themselves, to others and to the world around them. The motor act gains importance as an adaptive resource as it plays a role in the interaction between the subject and the environment, with the body serving as a means of communicative expression that the child uses to aid in the formation of mental representations of the world from these experiences, a process that begins in the sensory motor intelligence period.

Attempts to conceptualize psychomotricity date as far back as the 60's. As Berruezo (1996) points out, the concept has been defined in many different contexts, situations, and countries, and this is why there has been little agreement between professionals from different fields. Its deployment by professionals was not as clearly defined as was the case for other disciplines such as physiotherapy and physical activity, and there was confusion as to which terminology was best used to describe it, as it could be seen as a discipline (motion science), as a technique (psychomotor practice) or as a synonym of bodily activity (psychomotor ability). In light of these limitations and the lack of research on the topic, the present study attempts to contribute to the conceptualization of psychomotricity in the educational domain. In this sense, psychomotor education can exert an influence on affective, psychomotor, and cognitive areas, but it must be taken into account that affective and psychomotor areas tend to take a back seat after the end of preschool, when intellectual learning (with cognitive goals) occupies most of the school day.

The concept «psychomotor» contains the term «psycho», which refers to the psychological activity at the cognitive and affective levels, and the term «motor», which refers to movement. Thus, psychomotricity can be defined as the faculty that allows for, facilitates, and enhances physical, psychological and social development in children through movement (Herrera \& Ramírez, 1993). The concept rests on an evolutionary idea according to which an interaction between neuromotor (motor development) and psychological functions (cognitive and affective development) takes place in the course of a unique and unidirectional process wherein the child's body is the main element in touch with the environment.

There have been several theoretical approaches to this topic. Guilmain (1935), was the first to describe psychomotor education, and highlighted the impor- tance of movement to cognitive development. This author underlined the fact that before verbal language emerges, children use movement (gestures) in connection to their needs in situations that arise from their relationship with the environment. He also introduced emotion as a means of establishing communication with the environment. Vayer (1978) highlighted the educational nature of psychomotricity, maintaining that its goal is to teach motor skills and psychomotor behaviours that allow for improved social and academic outcomes. In his book «L'enfant face au monde», the author argued that psychomotor education must be incorporated into general education plans, as it could be a common factor affecting many aspects of education.

Lapierre and Aucouturier (1985) introduced a dynamic approach based on the analysis of movement from the perspectives of neurology, epistemology and semantics. Their methodology allowed children to freely experience different educational situations through self-discovery, which sparked improvements in psychomotor expression and the development of creativity. It also facilitated free and spontaneous communication and the sharing of experiences with the social group, and allowed children to develop at their own pace. According to Aucoutourier (2004), psychomotricity can be seen as a cross-cutting aspect with an important role in the development of a balanced personality. It is involved in several intervention areas such as prevention, education and therapy. The present work is based on Aucoutourier and his colleagues' approach.

In recent years, there has been a growing research interest in the effects of physical activity in general on cognitive abilities. In 1997, Meyer and Kiereas argued that executive abilities are among the cognitive aspects that benefit more from physical activity in children. A recent study showed that performing systematic physical activity significantly increased attentional performance by 15 to $25 \%$ in children (Moratal, Huertas, Boltá, Zahonero, \& Lupiañez, 2008). The research demonstrated that regular physical activity improved general cognitive abilities and that children who engaged in such planned activities were 15\% faster in reaction time tasks, while children who performed limited physical activity made $7 \%$ more errors in these tasks. The study also showed that children who played team sports such as football, basketball, handball and hockey had a $25 \%$ improvement in their ability to distinguish between relevant and irrelevant stimuli, and a $15 \%$ increase in their ability to discriminate between similar stimuli, compared to those who took part in individual sports such as swimming, running and cycling. Castelli, Hillman, Buck, and Erwin (2007) also pointed out that aerobic capacity is related to a better academic achievement in primary school, especially in mathematics and reading.

Other researchers have suggested that physical activity produces electrophysiological changes due to an increased activation of specific brain frequencies. 
For example, evoked potential studies (ERP) have revealed changes in P300, a component that is also involved in cognitive control processes (Mecklinger, Kramer \& Strayer, 1992). Along the same lines, Hillman, Erickson, and Kramer (2008), concluded that physical activity has a positive impact on cognition across a person's lifespan, and that these effects are due to an increase in blood flow to the brain. Moreover, studies on animals (Pereira, Huddleston, Brickman, Sosunov, Hen, \& McKhann, 2007) have recently shown that cellular changes can be caused by physical activity, as it enhances neurogenesis and prevents neurodegeneration of different areas of the brain. From a practical point of view, little is known about the best way to design intervention programs in order to have the greatest possible effects on cognition. However, knowledge from neuroscience could be readily applied to the development of new procedures to help enhance teaching and learning processes.

In summary, the vast majority of studies conducted to date have addressed the effects of physical activity on cognition, but there have only been a few studies on the effects of psychomotor activity at an early age. Piek, Dawson, Smith, and Gasson (2008) carried out a longitudinal study in order to determine whether fine and gross motor development affected later cognitive abilities. They found that early gross motor development was associated with better executive functions at school age. Along the same lines, Murray et al. (2006) found that motor performance at up to 4 years of age predicts cognitive abilities at school age. Other studies have addressed the relationship between motor capacity and academic achievement (Kurdek \& Sinclair, 2001), and between motor capacity and emotional development in infants (Piek, Barrett, Smith, Rigoli, \& Gasson, 2010; Sigurdsson, van Os, \& Fombonne, 2002). All these studies point out that early detection of motor disabilities before school age can predict potential problems in cognitive, academic and emotional development at older ages.

Thus, the present study aims to determine whether performing psychomotricity furthers the cognitive development of children starting at 11 months of age, an age at which the child has already started crawling and can explore his or her environment easily. As vision and action become more coordinated, children acquire better control of their movements and so become more aware that their acts have effects on the environment, that is, they learn cause-effect relationships related to their own movement. If psychomotricity improves cognition, differences in developmental and cognitive scores should be expected between phases in children who performed psychomotricity sessions once or twice per week compared to those who did not receive any sessions. We included a group of children who performed two sessions per week in order to observe whether performing psychomotricity more systematically has an even more beneficial effect on cognition.

\section{Methods}

\section{Participants}

Thirty infants between 11 and 22 months of age, all born in 2011, from a public school in a small village near Barcelona (17,000 inhabitants) participated in the study. The families came from an upper-middle class sociocultural background and had all chosen to send their children to this school, where the educational project is based on psychomotor education. Initially the children displayed normal development according to their chronological age.

There were three different groups: One group consisted of 12 children, 10 boys and 2 girls aged between 11 and 15 months at the beginning of the study ( $M=$ 12.42 months $S D=1.38$ ) who did not perform any psychomotricity (control group). Group 1 included 9 children, 3 boys and 6 girls aged between 15 and 22 months pre-intervention $(M=18.56, S D=2.60)$, who received one weekly session, and Group 2 consisted of 9 children, 5 boys and 4 girls, aged between 16 and 22 months pre-intervention $(M=19.00, S D=2.35)$ who received two sessions per week.

\section{Materials}

Two instruments were used: The Merrill-Palmer-R test and the Psychomotor Parameter Observation test. The Merrill-Palmer-R test (Roid \& Sampers, 2011) is an individual battery that assesses general development (General Index) in children from 0 months to 6.5 years of age, and explores five broad areas: a) cognitive development, which evaluates verbal and non-verbal reasoning, memory, visual-motor coordination, and speed of processing, b) motor skills development, which assesses fine and gross motor skills, c) language and communication skills, which evaluates receptive and expressive language, d) socio-affective development and e) adaptive behavior, which explores the degree and quality of social and affective relationships through parent questionnaires. In the present study, only the General Index, Cognitive and Motor skills development were assessed, as they are the most closely related to the aims of the study.

In addition, the Psychomotor Parameter Observation Test (Arnaiz \& Bolarin, 2000), which assesses children's psychomotor level, was employed. However, this observational test was only used as a control test in order to ensure that all the children who took part in the study had achieved a level appropriate to their age.

\section{Design and Procedure}

Before the intervention, all groups were administered the selected Merrill-Palmer-R scales in order to establish the baseline. Psychomotricity sessions were then administered over a period of five months (from November 2012 to March 2013) to the experimental groups (those who received one or two sessions per week). 
Table 1. Mean scores (standard deviations) for each group pre and post-intervention

\begin{tabular}{|c|c|c|c|c|c|c|}
\hline \multirow[t]{2}{*}{ Group } & \multicolumn{3}{|c|}{ Pre-Intervention } & \multicolumn{3}{|c|}{ Post-Intervention } \\
\hline & GI & Cognition & Motor Ability & GI & Cognition & Motor Ability \\
\hline 0 & $385.00(4.37)$ & $389.58(6.53)$ & $385.25(3.60)$ & 389.75 (2.49) & $393.08(3.60)$ & $389.00(6.08)$ \\
\hline 2 & $397.22(7.07)$ & $380.00(4.18)$ & $398.78(8.54)$ & 408.67 (3.64) & $403.44(5.89)$ & $408.56(2.51)$ \\
\hline Total Mean & 392.77 (8.44) & $388.70(8.32)$ & 393.03 (8.99) & $400.50(9.52)$ & 398.97 (6.41) & $400.67(10.49)$ \\
\hline
\end{tabular}

Note: Group 0: Control. Group 1: One session per week, Group 2: Two sessions per week. GI: General Index

Each session lasted 45 minutes and consisted of three brief episodes: welcoming the group as a whole and preparation for the session, free playing that involved motor movements such as balancing, jumping, falling, crawling etc. and the end of the session, when the group came together again. The session design was based on Aucouturier's methodology (2004), according to which the main focus is the free and spontaneous movement in infants' interactions with their environment on physical, symbolic and cognitive levels. This methodology is approved by the European Association of Psychomotor Practice and Training Schools (ASEFOP).

Our method employs relational psychomotricity because it gives the child an opportunity to interact with certain kinds of materials, with peers and adults. The sessions are divided into three phases:

- First ritual: welcoming of participants, with a conversation about various topics: reminders about rules and instructions, a review of the experiences of previous sessions, calling attention to the features of the room (materials, organization ...), projections of games to be played, etc. This section also serves to prepare the body for action: sometimes participants stamp their feet, while other times they rub their bodies, or sing songs ... It's about creating an atmosphere of participation that awakes desires for action.

- Experience time: the moment when the child acts in a situation where organic and natural forms of movement take on a key role, and the child experiences moments in which he or she is able to display emotions, feelings, affections, skills and knowledge. The children react quickly and reflexively. We organize the space, the time and the materials, and give the children room to allow for spontaneous motor activity and games to encourage basic exploration, discovery and gathering of knowledge about their environment.

- Final ritual: a coming together to indicate the end of the session, separation, and time to move on to another educational space. Here, we can discuss what has happened during the session, share the productions of representation, tell a story in order to remember the moments we have shared, sing a song ... The psychomotor room takes on the character of a special place for the child, a place for motion for the sake of pleasure.

The control group did not participate in these sessions, but instead engaged in other activities that are part of the usual school day.
After the intervention, the Merrill-Palmer-R test was administered again. Therefore, a pre-test/post-test with control group design was used.

\section{Results}

The developmental scores (General Index, Cognition and Motor ability) obtained by the three groups before and after intervention are shown in Table 1.

The pre-intervention raw developmental scores were subtracted from those obtained after the intervention for each group in order to calculate the mean differences between pre and post scores for each measure within a group. In other words, the aim was not strictly to compare the groups, but rather to determine whether the intervention significantly enhanced the difference between pre and post in a particular group compared to the others, for any of the variables.

The mean differences between pre and post were subjected to a one-way ANOVA, which showed that the three factors were significant: General Index $F(2,27)=4.715, p=.018)$, Cognition $F(2,27)=51.186$, $p<.001)$, and Motor Ability $F(2,27)=4.129, p=.027)$. Multiple comparisons showed that General Index only improved significantly between phases in Group 2 compared with Group 0 -control group- $(p=.005)$ but not compared with Group 1 ( $p=.152)$. Group 1 did not differ from Group 0 ( $p=.148)$. Regarding Cognition, Group 2 significantly improved between phases compared with both Group 0 and Group 1 ( $p<.001)$, but Group 1 did not differ from Group 0 ( $p=.219)$. Finally, regarding Motor Ability, both Group 1 and Group 2 differed significantly from Group 0 ( $p=.016$ and $p=.033$ respectively). Groups 1 and 2 did not differ between them $(p=.759)$. These results can be seen in Figure 1 .

\section{Discussion}

Psychomotricity has been approached from several perspectives, but has recently been the subject of growing interest in the fields of Psychology and Pedagogy. Psychomotor educators have focused mainly on carrying out interventions designed to improve children's development from an educational and therapeutic point of view, while also targeting children with learning difficulties. According to Aucoutorier (2004), through their own experience children discover which actions can be performed autonomously with their bodies, recognize different ways of moving, achieve goals, and discover balance. All these factors contribute to their becoming 


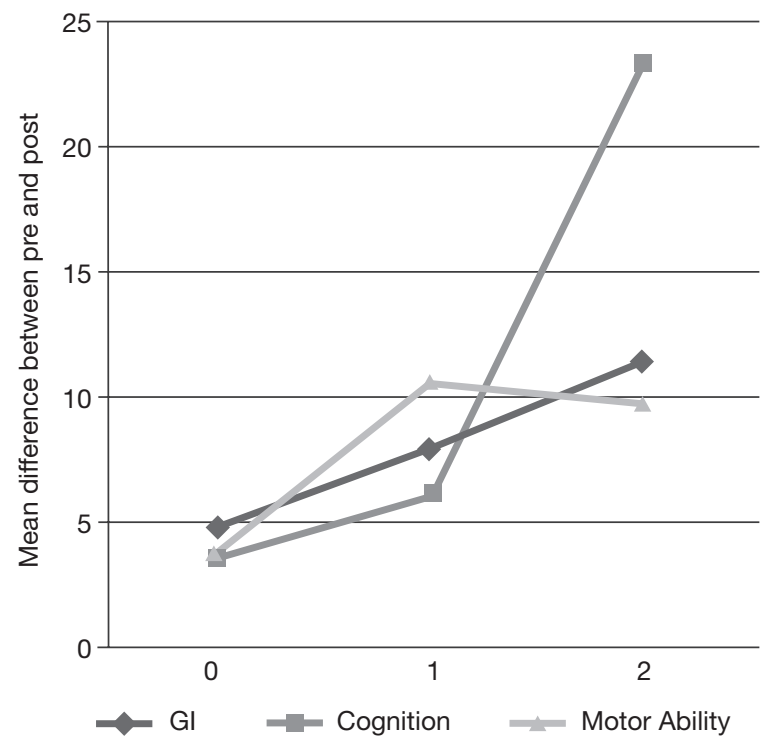

Figure 1. Mean differences in scores between pre and postintervention for each Group (0: control, 1: One session per week, 2: Two sessions per week).

aware of their own bodies, along with their environment, and to their discovery of the properties of objects and the sensorial experience of proprioceptive, interoceptive and exteroceptive cues. Collaboration, imagination and creative thinking are involved, along with freedom and confidence, factors which reflect a shift from the values of traditional pedagogy.

Although the ages of the children in the two groups were not equal at the beginning of the study, the results should be interpreted within each group, that is, to what extent the intervention positively enhanced the differences between phases. The present study shows that children from 11 months of age who perform psychomotricity systematically (two sessions per week) obtain higher scores for the general developmental index after the intervention as compared to their baseline than those who receive only one session or none.

These results suggest that systematically practicing psychomotor activity from a very early age can enhance general development, as children have more potentiality to perform any given task (thinking, monitoring, moving and relating to others). Hillman, Erickson, and Kramer (2008) argue that these beneficial effects persist in the long term. Regarding the cognition index, Meyer and Kieras (1997) suggest that the cognitive abilities that allow individuals to control and regulate their behaviour are the skills that most benefit from physical activity. In our study, psychomotricity also seems to improve cognition when performed systematically (two sessions per week). Finally, both groups who perform psychomotricity also improved in motor ability after their training. According to Herrero (2000), the motor act is an adaptive resource, and through it the child is able to internalize the external world. In this sense, performing psychomotricity once or twice a week enhances general motor abilities and thus allows children to improve their interaction with their environment.
Therefore, the present study shows that psychomotricity is a valid tool that contributes to children's development and helps future learning. Movement can improve the formation of cognitive structures related to attention, memory, perception, language, and thinking, all of which will help in the interpretation of concepts such as spatiality, temporality and speed. Moreover, their own movement becomes more autonomous and conscious through language and expression. Our results suggest that systematizing bodily experiences over the first months of life facilitates the emergence of motor and cognitive skills and also leads to expanded acquisition of emotional and affective content. Therefore, we highlight the importance of using the whole body in acts of symbolic playing, spontaneity, gestures and postures as means of expression in the first months of life. It is a crucial period of time during which children develop new abilities and lay the foundation for future learning. In some countries such as France, psychomotricity has already been officially implemented in educational centres. However, in others, the role of the psychomotrician has not yet been recognized beyond therapeutic and re-education contexts. As this study shows, systematic psychomotricity practice could be a good methodology to make a regular part of educational programmes, and could enhance children's abilities and improve their general development. From this perspective, we view psychomotor education, when it is undertaken from a pedagogical standpoint that is active, critical and flexible, as a path leading toward advances in the development of children's intellectual, emotional and social skills.

\section{References}

Aucouturier, B. (2004). Los fantasmas de la acción [Phantoms of the action]. Barcelona: Editorial Graó.

Arnáiz, P., \& Bolarín, M.J. (2000). Guía para la observación de los parámetros psicomotores [Guide for observation of psychomotor parameters]. Revista Interuniversitaria de Formación del Profesorado, 37, 67-85.

Berruezo, P. P. (1996). Psicomotricidad en España [Psychomotricity in Spain]. Psicomotricidad: Revista de estudios y experiencias, 53, 57-65.

Castelli, D.M., Hillman, Ch.H., Buck, S.M., \& Erwin, H.E. (2007). Physical Fitness and Academic Achievement in Third- and Fifth- Grade Students. Journal of Sport \& Exercise Psychology, 29, 239-252.

Guilmain, E. (1935). Fonctions psycho-motrices et troubles du comportement [Pyschomotor functions and behavioral problems]. París: Foyer central d'hygiène.

Herrera, F., \& Ramírez, I. (1993). La Psicomotricidad [Psychomotricity]. Revista INFAD, 5, 25-33.

Herrero, A. B. (2000). Intervención psicomotriz en el primer ciclo de educación infantil: estimulación de situaciones sensoriomotoras [Psychomotor intervention during first years of education: estimulation os sensory-motor situations]. Revista Interuniversitaria de Formación del Profesorado, 37, 87-102. 
Hillmam, Ch. H., Erickson, K.I., \& Kramer, A.F. (2008). Be smart, exercise your heart: Exercise effects on brain and cognition. Nature, 9, 58-65.

Kurdek, L. A., \& Sinclair, R. J. (2001). Predicting reading and mathematics achievement in fourth-grade children fromkindergarten readiness scores. Journal of Educational Psychology, 93, 451-455.

Lapierre, A. \& Aucoutorier, B. (1985). Simbología del movimiento [Movement symbology]. Barcelona: Ed. Científico-Médica.

Mecklinger, A., Kramer, A. F., \& Strayer, D. L. (1992). Event related potentials and EEG components in a semantic memory search task. Psychophysiology, 29, 104-119.

Meyer, D.E. \& Kieras, D.E. (1997). Computational Theory of Executive Cognitive Processes and Multiple-Task Performance: Part 2. Accounts of Psychological Refractory-Period Phenomena. Psychological Review, 104,4 749-791.

Moratal, C., Huertas, F., Boltá, R. S.; Zahonero, J., \& Lupiáñez, J. (2008). Las habilidades sociales en relación con el perfil atencional en fútbol base [Social abilities related to attentional profile in football players]. IV Congreso Internacional y XXV Nacional de Educación Física. Universidad de Córdoba.

Murray, G. K., Veijola, J., Moilanen, K., Miettunen, J., Glahn, D. C.,Cannon, T. D., et al. (2006). Infant motor development is associated with adult cognitive categorisation in a longitudinal birth cohort study. Journal of Child Psychology and Psychiatry, 47, 25-29.

Pereira, A. C., Huddleston, D. E., Brickman, A. M., Sosunov, A. A., Hen, R., \& McKhann, G. M. (2007). An in vivo correlate of exercise-induced neurogenesis in the adult dentate gyrus. Proceedings of the $\mathrm{Na}$ tional Academy of Science, 104, 5638-5643.

Piek, J. P., Barrett, N. C., Smith, L. M., Rigoli, D., \& Gasson, N. (2010). Do motor skills in infancy and early childhood predict anxious and depressive symptomatology at school age? Human Movement Science, 29, 777-786.

Piek, J. P., Dawson, L., Smith, L. M., \& Gasson, N. (2008). The role of early fine and gross motor development on later motor and cognitive ability. Human Movement Science, 27, 668-681.

Roid, G.H., \& Sampers, J.L. (2011). Merrill-Palmer-R. Escalas de desarrollo. Madrid: TEA.

Sigurdsson, E., van Os, J., \& Fombonne, E. (2002). Are impaired childhood motor skills a risk factor for adolescent anxiety? Results from the 1958U.K. birth cohort and the national child development study. The American Journal of Psychiatry, 159, 1044-1066.

Vayer, P. (1978). L'enfant face au monde: à l'âge des apprendtissages scolaires [The child in front of the world: the age of scholar learning]. Ed. Doin

\section{¿Puede la psicomotricidad mejorar la habilidades cognitivas en los bebés?}

Resumen. El objetivo del presente estudio es determinar si la participación en un programa de psicomotricidad a una edad temprana mejora la cognición. Treinta bebés (de 11 a 22 meses de edad) participaron en el estudio. El test Merrill-Palmer-R se administró antes de la intervención con el fin de medir el Índice General de Desarrollo, Cognición y habilidades motoras. Un grupo de niños realizó una sesión de psicomotricidad por semana, otro grupo recibió dos sesiones por semana, y un tercer grupo -control- no realizar ninguna sesión. Después de la intervención, las escalas del test se administraron de nuevo. El grupo que recibió dos sesiones semanales obtuvo las puntuaciones más altas en todas las medidas después de la intervención en comparación con el nivel basal. Los resultados sugieren que la práctica sistemática de la psicomotricidad puede mejorar el desarrollo general y la cognición en los bebés, por lo que podría ser útil para implementar esta metodología en la intervención educativa.

Palabras clave: Psicomotricidad; cognición; desarrollo; bebés 